\title{
CHARACTERIZATION OF SLOVAK CASTOR GENOTYPES (RICINUS COMMUNIS L.) USING MOLECULAR MARKERS
}

\author{
Vivodík Martin*, Petrovičová Lenka, Balážová Želmíra, Gálová Zdenka
}

Slovak University of Agriculture in Nitra, Faculty of Biotechnology and Food Sciences, Department of Biochemistry and Biotechnology

The aim of this work was to detect genetic variability among the set of 30 castor genotypes using 6 RAPD markers. Amplification of genomic DNA of 30 genotypes, using RAPD analysis, yielded 42 fragments, with an average of 7.00 polymorphic fragments per primer. Number of amplified fragments ranged from 5 to 9, with the size of amplicons ranging from 100 to 1,200 bp. The polymorphic information content (PIC) value ranged from 0.662 to 0.855 with an average of 0.780 and diversity index (DI) value ranged from 0.669 to 0.857 with an average of 0.785 . The dendrogram based on hierarchical cluster analysis using UPGMA algorithm was prepared. Knowledge on the genetic diversity of castor can be used for future breeding programs for increased oil production to meet the ever increasing demand of castor oil for industrial uses as well as for biodiesel production.

Keywords: castor; genetic diversity; molecular markers; RAPD technique

\section{Introduction}

Castor (Ricinus communis L., $2 n=2 x=20$, Euphorbiaceae Juss.), is industrially important non-edible oilseed crop widely cultivated in the arid and semi-arid regions of the world (Govaerts et al., 2000). The seeds of castor contain more than 45\% oil and this oil is rich (80-90\%) in an unusual hydroxyl fatty acid, ricinoleic acid (Jeong and Park, 2009). Castor oil is the only vegetable oil soluble in alcohol, presenting high viscosity, and requiring less heating than others oils during the production of biodiesel (Jeong and Park, 2009). Due to its unique chemical and physical properties, the oil from castor seed is used as raw material for numerous and varied industrial applications, such as: manufacture of polymers, coatings, lubricants for aircrafts, cosmetics, etc, and for the production of biodiesel (Jeong and Park, 2009). With more than $95 \%$ of the world's castor production concentrated in limited parts of India, China, and Brazil (Sailaja et al., 2008), and because of the ever increasing world-wide demand of castor for industrial use, there is a pressing need to increase the hectarage and productivity of castor. Castor is a cross pollinated crop and is usually cultivated as a hybrid in India, as hybrids give significantly greater yields than pure lines or varieties (Birchler et al., 2003; Reif et al., 2007). Higher magnitude of heterosis and genetically superior hybrids can be obtained by combining diverse parents in hybrid development. Conventional diversity analysis methods, in the field, are time consuming, laborious, resource intensive and drastically affected by environmental factors, therefore, a technique that is

*Corresponding author: Martin Vivodík, Slovak University of Agriculture in Nitra, Faculty of Biotechnology and Food Sciences, Department of Biochemistry and Biotechnology, $\triangle$ vivodikmartin@gmail.com 
rapid and not affected by environment is needed for assessment of genetic diversity and selection of parental lines for use in hybrid development programmes (Santalla et al., 1998).

Genetic diversity assessment prior to developing hybrids can aid in better exploitation of heterosis. Assessment of genetic variation using molecular markers appears to be an attractive alternative to the conventional diversity analyses and can also aid in management and conservation of biodiversity. A large number of polymorphic markers are required to measure genetic relationships and genetic diversity in a reliable manner (Santalla et al., 1998).

The aim of this study was to detect genetic variability among the set of 30 castor genotypes using 6 RAPD markers.

\section{Materials and methodology}

\section{Plant material and DNA extraction}

Ricin lines (30) were obtained from the breeding station Zeainvent Trnava Ltd. (Slovakia). DNA of 30 genotypes of castor was extracted from 10 day old leaves using the Gene JET Plant Genomic DNA Purification Mini Kit.

\section{RAPD amplification}

Amplification of RAPD fragments was performed according to Gajeraa et al. (2010) (Table 1) using decamer arbitrary primers (Operon technologies Inc, USA; SIGMA-D, USA). Amplifications were performed in a $25 \mu \mathrm{l}$ reaction volume containing $5 \mu \mathrm{l}$ DNA (100 ng), $12.5 \mu$ l Master Mix (Genei, Bangalore, India), and $1 \mu \mathrm{l}$ of $10 \mathrm{pmol}$ of primer. Amplification was performed in a programmed thermocycler (Biometra, Germany) with initial denaturation at $94{ }^{\circ} \mathrm{C}$ for $5 \mathrm{~min}, 42$ cycles of denaturation at $94^{\circ} \mathrm{C}$ for $1 \mathrm{~min}$, primer annealing at $38^{\circ} \mathrm{C}$ for $1 \mathrm{~min}$, extension at $72^{\circ} \mathrm{C}$ for $1 \mathrm{~min}$, and final extension at $72^{\circ} \mathrm{C}$ for $5 \mathrm{~min}$. Amplified products were separated in $1.5 \%$ agarose in $1 \times \mathrm{TBE}$ buffer. The gels were stained with ethidium bromide and documented using gel documentation system Grab-It 1D pre Windows.

Table 1 List of RAPD primers

\begin{tabular}{|l|c|c|}
\hline RAPD primers & Primer sequence (5' $\mathbf{~} \mathbf{3}^{\prime}$ ) & Molecular weight range, bp \\
\hline OPA-02 & TGCCGAGCTG & $400-2,800$ \\
\hline OPB-08 & GTCCACACGG & $530-1,550$ \\
\hline OPD-07 & TTGGCACGGG & $360-1,440$ \\
\hline OPE-07 & AGATGCAGCC & $300-1,940$ \\
\hline SIGMA-D-01 & AAACGCCGCC & $280-1,350$ \\
\hline SIGMA-D-P & TGGACCGGTG & $300-3,000$ \\
\hline
\end{tabular}

\section{Data analysis}

The RAPD bands were scored as present (1) or absent (0), each of which was treated as an independent character regardless of its intensity. A dendrogram based on hierarchical cluster analysis using the unweighted pair group method with arithmetic average (UPGMA) with the SPSS professional statistics version 17 software package was constructed. For the assessment of the polymorphism between genotypes ricin and usability RAPD markers in their differentiation we used diversity index (DI), the probability of identity (PI) and polymorphic information content (PIC). 


\section{Results and discussion}

PCR amplifications using 6 RAPD primers produced 42 DNA fragments that could be scored in all genotypes. The selected primers amplified DNA fragments across the 30 genotypes studied, with the number of amplified fragments varying from 5 (OPE-07) to 9 (OPD-07), and the amplicon size varying from 100 to 1,200 bp. Of the 42 amplified bands, all 42 were polymorphic, with an average of 7.00 polymorphic bands per primer. The polymorphisc information content (PIC) value varied from 0.662 (OPE-07) to 0.855 (OPD-07), with an average of 0.780 and index diversity (DI) value varied from 0.669 (OPE-07) to 0.857 (OPD-07) with an average of 0.785 (Table 2).

Table 2 The statistical characteristics of the RAPD markers used in castor

\begin{tabular}{|l|c|c|c|c|}
\hline Primers & Number of alleles & DI & PIC & PI \\
\hline OPA-02 & 8 & 0.778 & 0.776 & 0.016 \\
\hline OPB-08 & 7 & 0.805 & 0.794 & 0.010 \\
\hline OPD-07 & 9 & 0.857 & 0.855 & 0.009 \\
\hline OPE-07 & 5 & 0.669 & 0.662 & 0.071 \\
\hline SIGMA-D-01 & 6 & 0.817 & 0.811 & 0.019 \\
\hline SIGMA-D-P & 7 & 0.785 & 0.780 & 0.025 \\
\hline Average & 7.00 & 0.785 & 0.780 & 0.025 \\
\hline
\end{tabular}

$\mathrm{DI}$ - diversity index; PIC - polymorphic information content; PI - probability of identity

The dendrogram based on UPGMA analysis separated 30 genotypes into two groups. One ricin genotype RM-62 (cluster I) separated from others. Second group of 29 ricin genotypes (II) was divided into 3 main clusters $(1,2,3)$. Cluster 1 contained 11 ricin genotypes, cluster 2 contained 4 ricin genotypes (RM-61, RM-63, RM-71 and RM-57) and cluster 3 contained 14 ricin genotypes. We could not distinguish two genotypes, RM-65 and RM-66, which can be caused due the same genetic background (Figure 1).

Gajeraa et al. (2010) used 30 RAPD polymorphic primers for the analysis of 22 castor bean genotypes. RAPD analysis yielded 256 fragments, of which 205 were polymorphic, with an average of 6.83 polymorphic fragments per primer. Genetic diversity of 37 ricin genotypes grown in China using RAPD markers was studied by Li et al. (2012). Using RAPD markers, together they detected 122 alleles, of which 71 were polymorphic, representing the percentage of polymorphism alleles $58.20 \%$. In the study Machado et al. (2013) used 58 RAPD primers for the analysis of 15 castor bean cultivars. The genetic dissimilarity between cultivars was calculated by Jaccard's index, using the unweighted pairgroup method with arithmetic mean (UPGMA). Pecina-Quintero et al. (2013) study the diversity and genetic relationships among accessions of R. communis from the state of Chiapas, México using AFLP (amplified fragment length polymorphism) and SSR (simple sequence repeat) markers. Tomar Rukam et al. (2014) investigated the fingerprinting and phenotyping of 25 castor genotypes available in Gujarat and other States of India using RAPD and ISSR markers. One hundred thirty decamer RAPD primers from Operon series (OPA to OPZ five from each series) were screened with the DNA of the 2 castor genotypes. Some researchers have considered RAPD markers to represent segments of DNA with noncoding regions and to be selectively neutral (Landergott et al., 2001), and some studies have shown that RAPD markers are 
distributed throughout the genome and may be associated with functionally important loci (Penner, 1996).

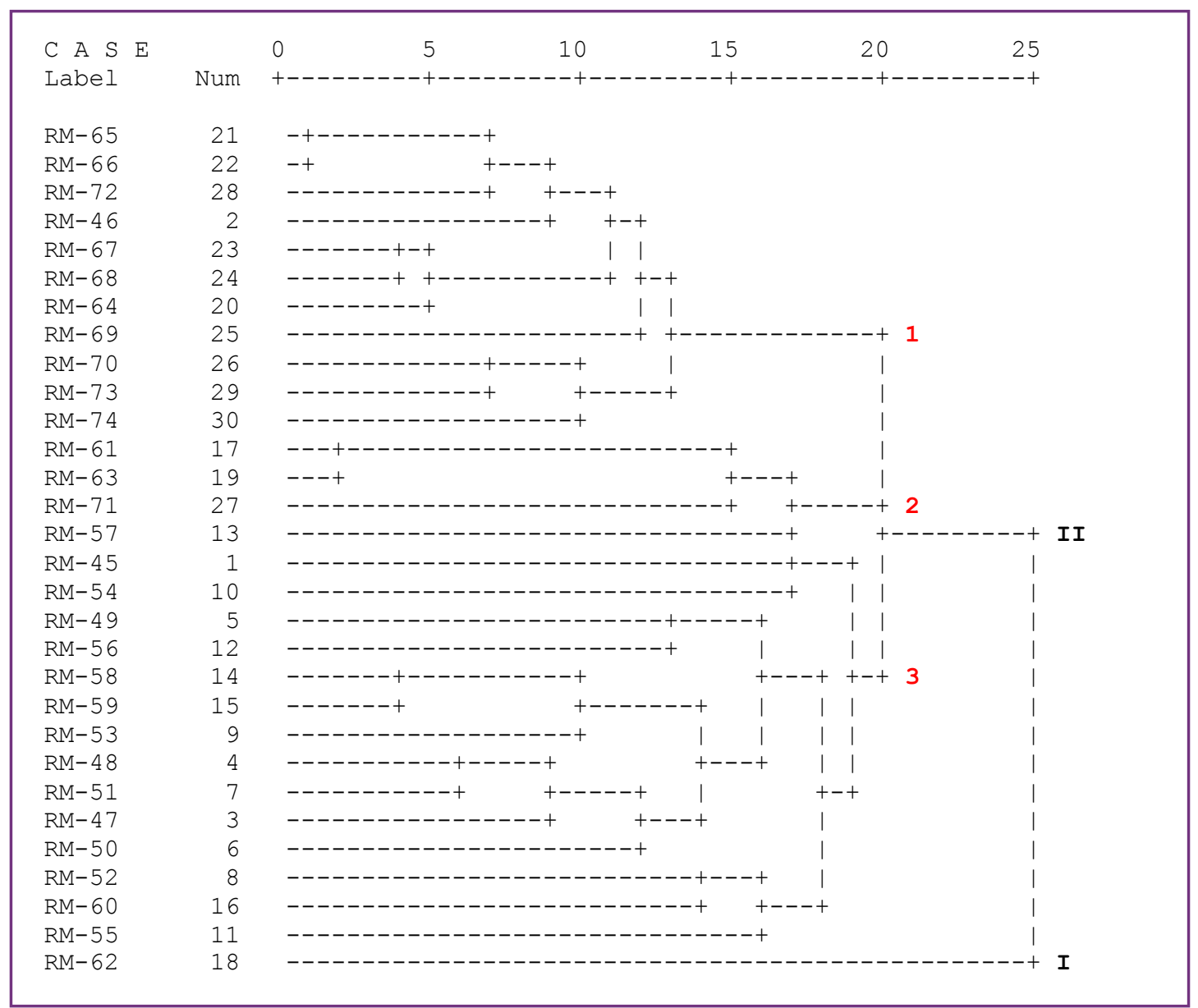

Figure 1 Dendrogram of 30 castor genotypes prepared based on 6 RAPD markers

\section{Conclusions}

The analysis showed that the RAPD markers are very effective molecular markers for the assessment of the genetic diversity in castor bean. The dendrogram prepared based on UPGMA algorithm separated unique genotype RM-62 from others and rest (29) of ricin genotypes divided into three main groups. Using 6 RAPD markers only two castor bean genotypes have not been distinguished. Our analysis proved utilization of RAPD markers for differentiation of used set of castor genotypes. For better discrimination of the analyzed ricin genotypes, it is necessary to use a higher number of RAPD markers.

\section{Acknowledgments}

This work was funded by European Community under project ITMS 26220220180: Building Research Centre "AgroBioTech" (50\%) and KEGA project No 021SPU-4/2015 (50\%). 


\section{References}

Birchler, J.A., Auger, D.L., Riddle, N.C. 2003. Search of the molecular basis of heterosis. Plant Cell, vol. 15, p. 2236-2239. DOI: 10.1105/tpc.151030

Gajeraa, B.B., Kumara, N., Singha, A.S., Punvara, B.S., Ravikirana, R., Subhasha, N., Jadejab, G.C. 2010. Assessment of genetic diversity in castor (Ricinus communis L.) using RAPD and ISSR markers. Industrial Crops and Products, vol. 32, p. 491-498. https://doi.org/10.1016/j.indcrop.2010.06.021

Govaerts, R., Frodin, D.G., Radcliffe-Smith, A. 2000. World Checklist and Bibliography of Euphorbiaceae (with Pandaceae). Trowbridge, Wiltshire. ISBN 9781900347839

Jeong, G.T., Park, D.H. 2009. Optimization of biodiesel production from castor oil using response surface methodology. Appl. Biochem. Biotechnol., vol. 156, p. 431-441. DOI: 10.1007/s12010-008-8468-9

Landergott, U., Holderegger, R., Kozlowski, G., Schneller, J.J. 2001. Historical bottlenecks decrease genetic diversity in natural populations of Dryopteris cristata. Heredity, vol. 87, p. 344-355. https://www.ncbi. nlm.nih.gov/pubmed/11737281

Li, F.J., Wang, C.L., He, D., Liu, Z.Q., Chen, M.H., Wang, Y.R., Li, F.J., Yang, Z.H., Chen, G. 2012. Evaluation ofgenetic diversity in Castor (Ricinus communis L.) using RAPD markers. Advanced materials research, vol. 343-344, p. 981-987. DOI:10.4028/www.scientific.net/AMR.343-344.981

Machado, E.L., Silva, S.A., Santos, A.S., Bastos, L.A., Pestana, C.N., Dos Santos K.S., Ferreira, C.F., Diamantino, M.S.A.S. 2013. Genetic dissimilarity between castor bean cultivars using RAPD markers. Pesq. agropec. bras., vol. 48, no. 3, p. 342-345. http://dx.doi.org/10.1590/S0100-204X2013000300014

Pecina-Quinteroa, V., Anaya-Lópeza, J.L., Nú̃nez-Colína, C.A., Zamarripa-Colmenerob, A., Montes-Garcíac, N., Solís-Bonilla, J.L., Aguilar-Rangel, M.R. 2013. Assessing the genetic diversity of castor bean from Chiapas, México using SSR and AFLP markers. Industrial Crops and Product., vol. 41, p. 134-143. https:// doi.org/10.1016/j.indcrop.2012.04.033

Penner, G.A. 1996. RAPD analysis of plant genomes. Methods of Genome Analysis in Plants. CRC Boca Raton, p. 251-268.

Reif, J.C., Gumpert, F.M., Fischer, S., Melchinger, A.E. 2007. Impact of interpopulation divergence on additive and dominance variance in hybrid populations. Genetics, vol. 176, p. 1931-1934. DOI: 10.1534/ genetics.107.074146

Sailaja, M., Tarakeswari, M., Sujatha, M. 2008. Stable genetic transformation of castor (Ricinus communis L.) via particle gun-mediated gene transfer using embryo axes from mature seeds. Plant Cell Rep., vol. 27, p. 1509-1519. DOI: 10.1007/s00299-008-0580-3

Santalla, M., Power, J.B., Davey, M.R. 1998. Genetic diversity in mung bean germplasm revealed by RAPD markers. Plant Breed., vol. 117, p. 473-478. DOI: 10.1111/j.1439-0523.1998.tb01976.x

Tomar Rukam, S., Parakhia, M.V., Kavani, R.H., Dobariya, K.L., Thakkar, J.R., Rathod, V.M., Dhingani, R.M. And Golakiya, B.A. 2014. Characterization of castor (Ricinus communis L.) genotypes using different markers. Res. J. Biotech, vol. 9, no. 2, p. 6-13. file:///C:/Users/Acer/AppData/Local/Temp/castor.pdf 